\title{
PETROLEUM POTENTIALITY AND PETROPHYSICAL EVALUATION OF THE MIDDLE-JURASSIC SARGELU FORMATION, NORTHERN IRAQ
}

\author{
Wrya J. Mamaseni \\ Department of Geology, College of Science, Salahaddin University, Erbil, Iraq \\ Email:wrya.jabbar@su.edu.krd \\ Received: 3 March 2020; accepted: 1 September 2020
}

\begin{abstract}
This study indicates the source rock evaluation and reservoir properties of the MiddleJurassic Sargelu Formation in two selected sections (well Atrush-3 and Warte outcrop) northern Iraq. The well log data display that the shale includes $30 \%$ of the upper part of the Sargelu Formation. This extraordinary ratio of shale content has negative impacts on the reservoir properties in this part of the formation. The lower part of the formation has a good porosity ratio that reaches $15 \%$ as calculated from the log data. The porosity is obtained from analyzed core samples support the same conclusion that obtained in the log data analysis and it is measured at 9-17.5\% for interval 1282-1301 $m$ in Atrush-3 well and 5-7.9\% in the interval 54-75 $m$ Warte section. The formation has very good organic matter quality for black shales as the average total organic carbon (TOC) measured from the pyrolysis assessments is about $2.61 \mathrm{wt} \%$ in both the well and the section. The low oxygen index (average $26 \mathrm{mg} \mathrm{CO}_{2} / \mathrm{g} \mathrm{TOC}$ ) and high hydrogen index (average $423 \mathrm{mg} \mathrm{HC/g} \mathrm{TOC}$ ) indicate the variation of the kerogen class from type II in the Atrush-3 to type II-III in the Warte section. These two forms of kerogen can produce oil and condensate gas in a suitable state. Pristine/phytane $(\mathrm{Pr} / \mathrm{Ph})$ ratios are less than one (0.67-0.83) and this reveals the anoxic condition for the formation. The colors of the palynomorphs in the examined samples under the microscope changes from yellowish brown to brown $(\mathrm{TAI}=+2,-3)$, and the average $T_{\max }$ and vitrinite reflectance are $444^{\circ} \mathrm{C}$ and 0.80 , respectively. Sargelu Formation is located within the mature and oil window. This is also supported by the carbon preference index which is around one (average 0.98).
\end{abstract}

Keywords: Sargelu Formation; Oil window; Mature stage; Atrush-3; Warte

\section{INTRODUCTION}

The Middle-Late Jurassic Megasequence was deposited during a period of isolation of the main intra-shelf basin of Mesopotamia from the neo-Tethyan ocean probably due to renewed 
rifting along the NE margin of the Arabian plate. The basin was bounded to the $\mathrm{W}$ by the N-S trending Rutba uplift, West of Iraq. Deposition within the basin occurred in a restricted, relatively deep-water environment during Middle Jurassic (Jassim and Goff, 2006). Middle Jurassic Sargelu is the most significant formation in northern Iraq. The formation in well Atrush-3 is discovered in depth interval 1261-1301 m between Alan and Barsarin formations, while the formation contacted with Neokelekan and Sekhanian formations in Warte outcrop section. This study is the first collaborative identification of source and reservoir rocks for the formation together. The formation is the basinal representative of the widespread transgression of the Middle Jurassic in Iraq. Sargelu Formation was acknowledged and pronounced by Wetzel at Surdash anticline in northern Iraq's High Folded Zone (Bellen et al., 1959). The lithological composition of the formation is rather uniform; typically, it consists of calcareous bituminous, black shale and limestone (Buday, 1980). The thickness of the formation in the zone of outcrops at the High Folded, Imbricated and northern Thrust Zones varies from 20-125m (Jassim and Goff, 2006); the thickness in the current area is $40 \mathrm{~m}$ in well Atrush-3, and $75 \mathrm{~m}$ in the outcrop (Warte). As in age-equivalent units throughout the Arabain Shield, the Sargelu Formation is comparable to parts of the Cudi Unit of SE Turkey (Altinli, 1966); in central Syria, it is equivalent to the black shale of the uppermost portion of the Dolaa Group (Dubertret, 1966); in both Saudi and southwest Iran, it is equivalent to Dhruma and the lower part of the Sarmeh formations respectively. Mamaseni et al., 2019 mentioned that the organic matter content in the source formations of northern Iraq is typing II $\geq$ I and II kerogen, which are highly oil prone. The main aims of this study are determined petrophysical characteristics of the formation based on well log data and core samples, in addition to potentiality of Sargelu Formation to hydrocarbon generation.

\section{GEOLOGICAL SETTING}

The Middle-Late Jurassic megasequence starts with the Muhaiwar Neritic Formation in the Rutba Subzone and the Sargelu Basinal Formation elsewhere in Iraq (Jassim and Goff, 2006). The study region is currently considered to be a significant hydrocarbon province. Indeed, the wide and box-shaped anticlines in the region are systems for hosting hydrocarbons. In such layers, the sealing ability of the corresponding thrusts must be carefully regarded. Several supplementary faults in the adjacent anticlines to the study area (in Atrush field) reveal trapping efficiency in the Triassic and Jurassic systems (Shamaran petroleum corporator, 2013). The selected sections are located inside the Zagros belt which is formed by subduction between two plates that are the Arabian and the Eurasian plates. The belt is located within the 
Arabian Plate's northeastern margin. In Atrush block, the well Atrush-3 which is located 85 $\mathrm{Km}$ northwest of Erbil City in the High Folded Zone has been selected. The subsurface layers of the Atrush block within the Zagros sedimentary basin is intensively folded and thrust although the outcrop (Warte) segment is situated northeast of the Erbil city within the Imbricated Zone, $145 \mathrm{Km}$ away from the city (Fig. 1). The region is a narrow belt that encompasses areas of High Folded Zone north and northeast. It is folded and thrust violently. Anticlines are broken into imbricates by thrusts and bypass synclines. The sedimentary cover in the High Folded Zone typically consists of rock units of Paleozoic (1.5-5 Km thick), Triassic (1.5-2 Km thick), Jurassic (1.1 Km thick), Cretaceous (1.05-2 Km thick), Paleogene (1-1.5 Km thick) and Neogeneous sediments which fill other synclines in the area with variable thickness (Jassim and Goff, 2006). In the Middle of the anticlines, the uncovered rocks are mostly Cretaceous, while Jurassic and Triassic rock units crop out in anticlines that are close to the Imbricated Zone.

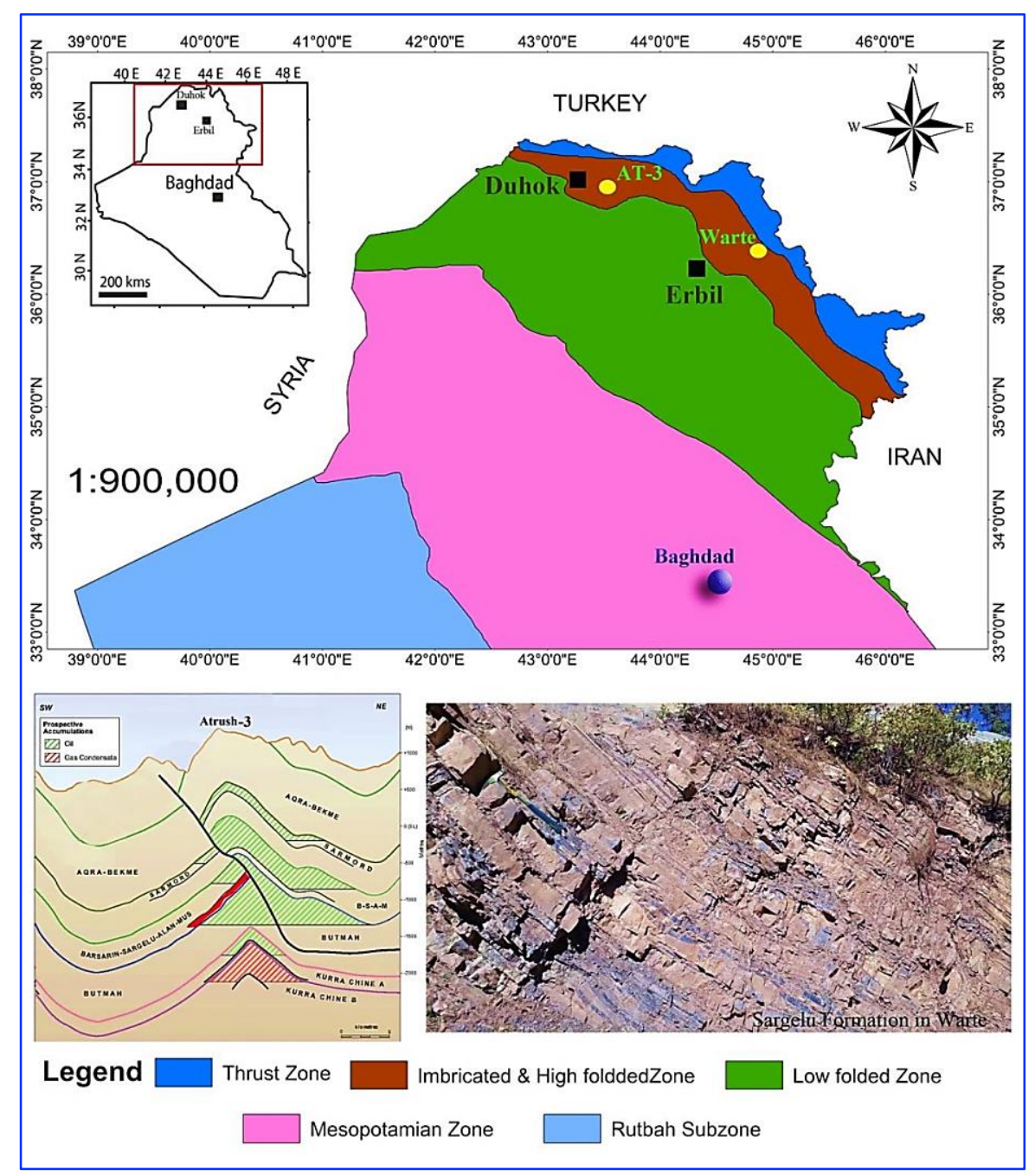

Fig. 1. Location map for the northeast Arabian Platform in Iraq, which shows Zagros Thrust-Fold Belt, including studied sections (Aqrawi et al., 2010) 


\section{MATERIALS AND METHODS}

\section{Porosity and Permeability}

In order to determine the porosity and permeability of the Sargelu Formation, eighteen core samples from borehole and surface sections were collected and analyzed. The $2.55 \mathrm{~cm}$ diameter and 2.5 to $5 \mathrm{~cm}$ length core samples have been extracted from the formation. The core plugs were toluene-cleaned and then dried up at $90{ }^{\circ} \mathrm{C}$ in an oven. The porosity and permeability of prepared core plugs were calculated using the porosimeter helium injection and the nitrogen injection, respectively. Measurements are carried out in UKH laboratory.

\section{Petrophysical Evaluation}

The most common types of well logs such as gamma ray, neutron porosity, bulk density and resistivity that are taken at depth intervals of 1261-1301 m in well Atrush-3 using interactive petrophysics (IP) software to identify the formation's most critical reservoir characteristics such as shale thickness, porosity and saturation. The gamma ray $\log (\mathrm{GR})$ is used to determine the volume of shale within the studied formation. The formation resistivity for its fluids and matrix (water and hydrocarbon) in the pores is true resistivity (Rt), which is typically gotten from deep resistivity log, however the resistivity of the flushing zone (Rxo) are measured by micro spherical focused logs (MSFL); both are used to estimate the type and amount of the liquids (HCs and water) between the pores. Basically, the formation water resistivity $\left(\mathrm{R}_{\mathrm{w}}\right)$, with Archie parameters such as cementation factor (m) and saturation exponent (n) are calculated from well log data via pickett plot method, which is relationship between effective porosity and true resistivity. The porosity $(\Phi)$ can be estimated from neutron (NPHI) and bulk density (RHOB). Finally, water saturation $\left(\mathrm{S}_{\mathrm{w}}\right)$ is calculated by Archie equation.

\section{Rock-Eval Pyrolysis}

Thirteen core samples from both sections are analyzed, using Rock-Eval pyrolysis to obtain total organic carbon (TOC) and pyrolysis parameters ( $\mathrm{S} 1, \mathrm{~S} 2, \mathrm{~S} 3$ and $\mathrm{T}_{\max }$ ). The analysis has been done at a scientific research center (Soran University). The artificial temperature in the laboratory gives the crashed samples, beginning at $300{ }^{\circ} \mathrm{C}$ and increasing to $650{ }^{\circ} \mathrm{C}$ in about 3 and 25 minutes, and then the temperature rises to $850{ }^{\circ} \mathrm{C}$ to get $\mathrm{S} 3$. The hydrogen index $(\mathrm{HI}=100 \times \mathrm{S} 2 / \mathrm{TOC}, \mathrm{mg} \mathrm{HC} / \mathrm{g}$ TOC$)$ and the oxygen index $\left(\mathrm{OI}=100 \times \mathrm{S} 3 / \mathrm{TOC}, \mathrm{mg} \mathrm{CO}_{2} / \mathrm{g}\right.$ TOC$)$ are expected when TOC is paired with S2 and S3; Free hydrocarbon (S1) as opposed to overall generative capacity $(\mathrm{GP}=\mathrm{S} 1+\mathrm{S} 2)$ to achieve production index $(\mathrm{PI})($ Table 2$)$. 


\section{Gas Chromatography (GC)}

Analysis of gas chromatography (GC) removes all components in a sample and provides a representative spectral output. The specimen injects into the GC device's injection tube. The GC instrument vaporizes the sample, and then the different components are isolated and analyzed. Ideally, each variable generates a specific spectral peak that can be reported on a paper map. The scale of the peaks in the measured specimen is equal to the amount of the related substances; the analysis has been done in MNR laboratory.

\section{Palynomorphs Study}

Separate microfossils (spores and pollen) from sediments used to detect color change under a projected microscope. The samples were prepared at Salahaddin University, Erbil, Department of Geology. For making palynological slides, carbonate and silicate materials dissolved in HCL and HF acids, the residue is sieved through $10 \mu \mathrm{m}$ nylon meshes then glass slides were equipped and the slides were inspected under a transmitted light microscope with magnifications of $250 \times$ to recognize different organic categories or particles.

\section{RESULTS AND DISCUSSION}

\section{Reservoir Properties}

\section{Porosity and permeability (core samples)}

Permeability and porosity are the two essential things in the reservoir rocks (Selley, 1998). Virtually porosity in carbonate rocks (limestone and dolomite) formed after deposition. Usually, there are two different forms of porosity, effective porosity (clean of shale) and total porosity (is the porosity that is calculated directly from logs without correction). Porosity is less than $5 \%$ in significant while more than $25 \%$ is exceptional porosity (Selley, 1998). The outcomes of the porosity and permeability of the Sargelu Formation are shown in (Table 1) accordingly, the formation in the well Atrush-3 was separated into two parts, the porosity ratio in the upper part ranges between $2-6.5 \%$ (poor porosity), while the lower part of the formation has good porosity (reaching to $17.5 \%$ ). By the way, the permeability at this interval (1261-1301 m) varies from $0.02-12 \mathrm{mD}$ which means that the liquids can flow inside the limestone beds. In comparison, the porosity ratio in the outcrop portion is poor throughout the section which varies from $1.2 \%$ to $7.9 \%$ (Fig. 2).

\section{Well log data analysis}

Gamma ray $\log$ is the most common log used for measuring the volume of shale in the formations. A low reading means low shale content while the reading is high when more shale volume is detected. 


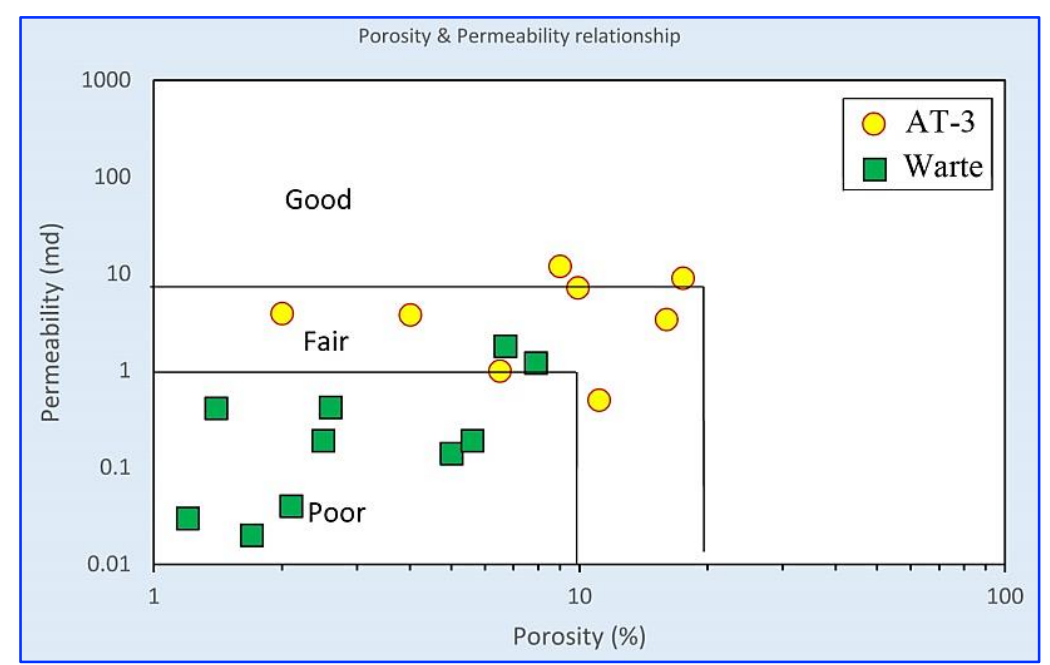

Fig. 2. Relationship between porosity $(\%)$ and permeability $(\mathrm{mD})$ of the Sargelu Formation in the studied sections

Table 1. Porosity and permeability of the Sargelu Formation in the studied sections

\begin{tabular}{|c|c|c|c|c|}
\hline 号 & Ü & $\operatorname{Depth}(\mathrm{m})$ & 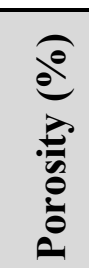 & 国 \\
\hline \multirow{8}{*}{$\stackrel{n}{\stackrel{9}{4}}$} & 1 & 1264 & 4 & 3.8 \\
\hline & 3 & 1271 & 2 & 3.9 \\
\hline & 4 & 1276 & 6.5 & 1 \\
\hline & 5 & 1282 & 11.1 & 0.5 \\
\hline & 6 & 1287 & 16 & 3.4 \\
\hline & 7 & 1291 & 9 & 12 \\
\hline & 7 & 1295 & 9.9 & 7.2 \\
\hline & 8 & 1298 & 17.5 & 9.1 \\
\hline \multirow{10}{*}{ 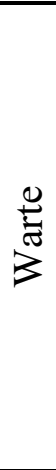 } & 1 & 3 & 1.2 & 0.03 \\
\hline & 2 & 9 & 1.4 & 0.41 \\
\hline & 3 & 16 & 1.7 & 0.02 \\
\hline & 4 & 25 & 2.1 & 0.04 \\
\hline & 5 & 33 & 2.6 & 0.42 \\
\hline & 6 & 45 & 2.5 & 0.19 \\
\hline & 7 & 54 & 5 & 0.14 \\
\hline & 8 & 65 & 5.6 & 0.19 \\
\hline & 9 & 69 & 7.9 & 1.2 \\
\hline & 10 & 74 & 6.7 & 1.8 \\
\hline
\end{tabular}

To notify the volume of shale within the Sargelu Formation (Middle Jurassic), Larionov old rock was used. For this purpose, gamma ray index is determined through equation 1 then the findings are used directly in equation 2. Regarding the planned formation is separated into two zones; the average volume of shale in the upper part is $30 \%$ whereas this value decreases 
to $10 \%$ for the lower most part of the formation. Shale volume content in any formation is more than $20 \%$ and cannot be considered as a good reservoir for accumulating hydrocarbons (Asquith and Krygowski, 2004).

$$
\begin{aligned}
\mathrm{IGR} & =\frac{\mathrm{GR} \log -\mathrm{GRmin}}{\mathrm{GR} \max -\mathrm{GRmin}} \\
V s h & =0.33\left(2^{2 * G R I}-1\right)
\end{aligned}
$$

After determining the volume of shale in the formation the relationship between neutron porosity and bulk density has been used to assess the lithology and measure the formation's porosity (Darwin and Julian, 2007); according to the crossplot the selected formation in well Atrush-3 consists mainly of limestone with some beds of dolomitic limestone (Fig. 3). On the cited crossplot, the porosity ratios for the lower part of the formation started from $1.7-18 \%$, while it has $0.01-8.9 \%$ porosity in the rest parts. Regarding, the results (based on laboratory and well log tests), only the lower most part of the formation in well Atrush-3 has sufficient porosity and permeability for moving and occupying hydrocarbons. To estimate the saturation of the Sargelu Formation in borehole section, firstly, pickett plot approach used (plotting deep resistivity versus effective porosity, both on logarithmic scales) to calculate water resistivity $\left(R_{w}\right)$, besides $R_{w}$ Archie's parameters which are cementation exponent $(m)$, tortuosity component (a) and saturation exponent (n) were determined which values are $a=1, m=1.99$ and $n=2$. The red line going between points that have the lowest deep resistivity and the maximum values of porosity reflect the water area where water concentration is equal to one (Fig. 4). Secondly, the saturations of the formation $\left(S_{w}\right.$ and $\left.S h c\right)$ has been detected; the saturation of the rock fluid reservoir is discussed to the quantity of pore space occupied with a given fluid, and the total of all pore space fluids is equal to one hundred percent (Dresser, 1975). Water Saturation $\left(S_{w}\right)$ is the sum of pore volume in a rock that has been filled with water since its formation. Water saturation shall be represented as a proportion or decimal fraction (Asquith and Krygowski, 2004). Archie's (1942) principle is used to estimate the $\mathrm{S}_{\mathrm{w}}$ of the uninvaded zone through equation 3 , then the hydrocarbon saturation deduced from water saturation by equation 4 .

$$
\begin{aligned}
& \mathrm{Sw}=\left(\frac{\mathrm{a}}{\emptyset^{\mathrm{m}}} * \frac{\mathrm{Rw}}{\mathrm{Rt}}\right)^{\frac{1}{\mathrm{n}}} \\
& \mathrm{Shc}=1-\mathrm{Sw}
\end{aligned}
$$

Only the lower part of the formation was saturated and it paid $2.75 \mathrm{~m}$ from the total 40 $\mathrm{m}$ thick. There are two different types of hydrocarbons such as mobile and residual, mobile 
hydrocarbon signified with a yellow color on computer processing interpretation while residual hydrocarbon with a green color (Fig. 5), the limestone beds include both residual and mobile hydrocarbon.

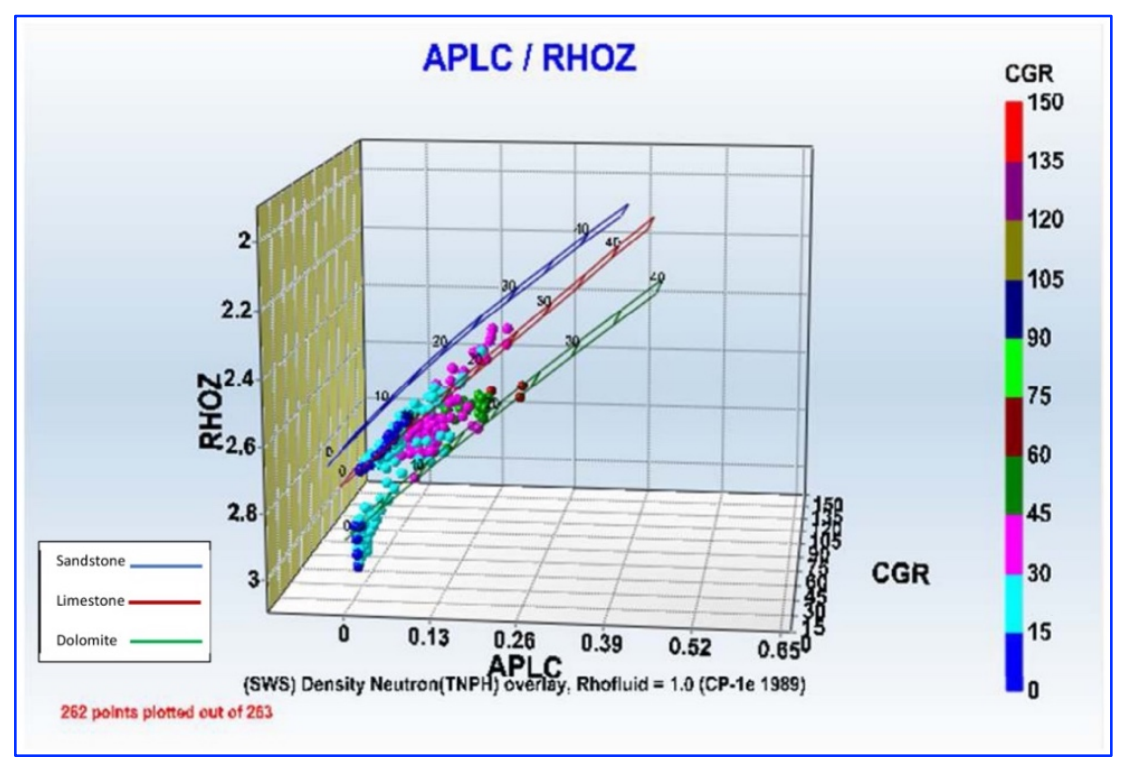

Fig. 3. Neutron-density cross plot for the Sargelu Formation in well Atrush-3

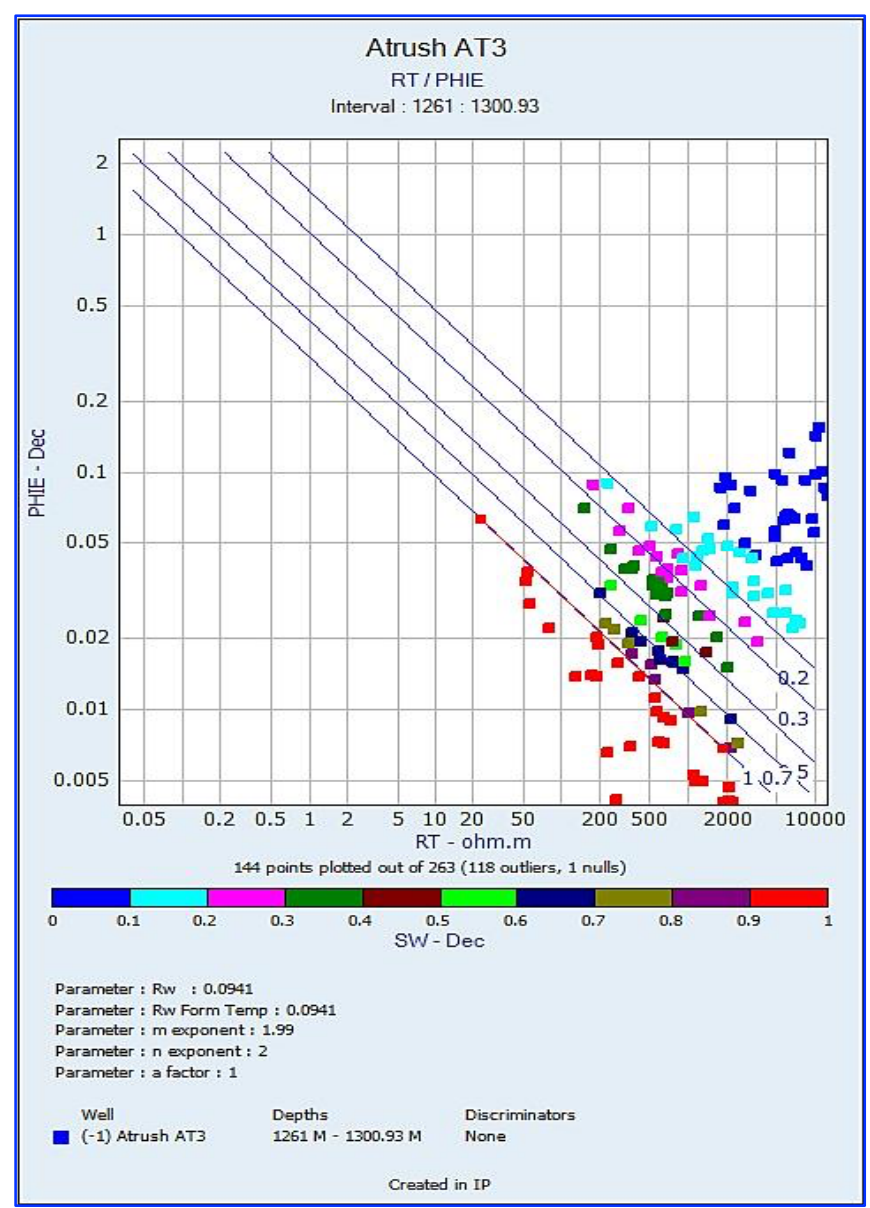

Fig. 4. True formation resistivity versus effective porosity used to calculate formation water resistivity $\left(\mathbf{R}_{\mathrm{w}}\right)$ in well Atrush-3 


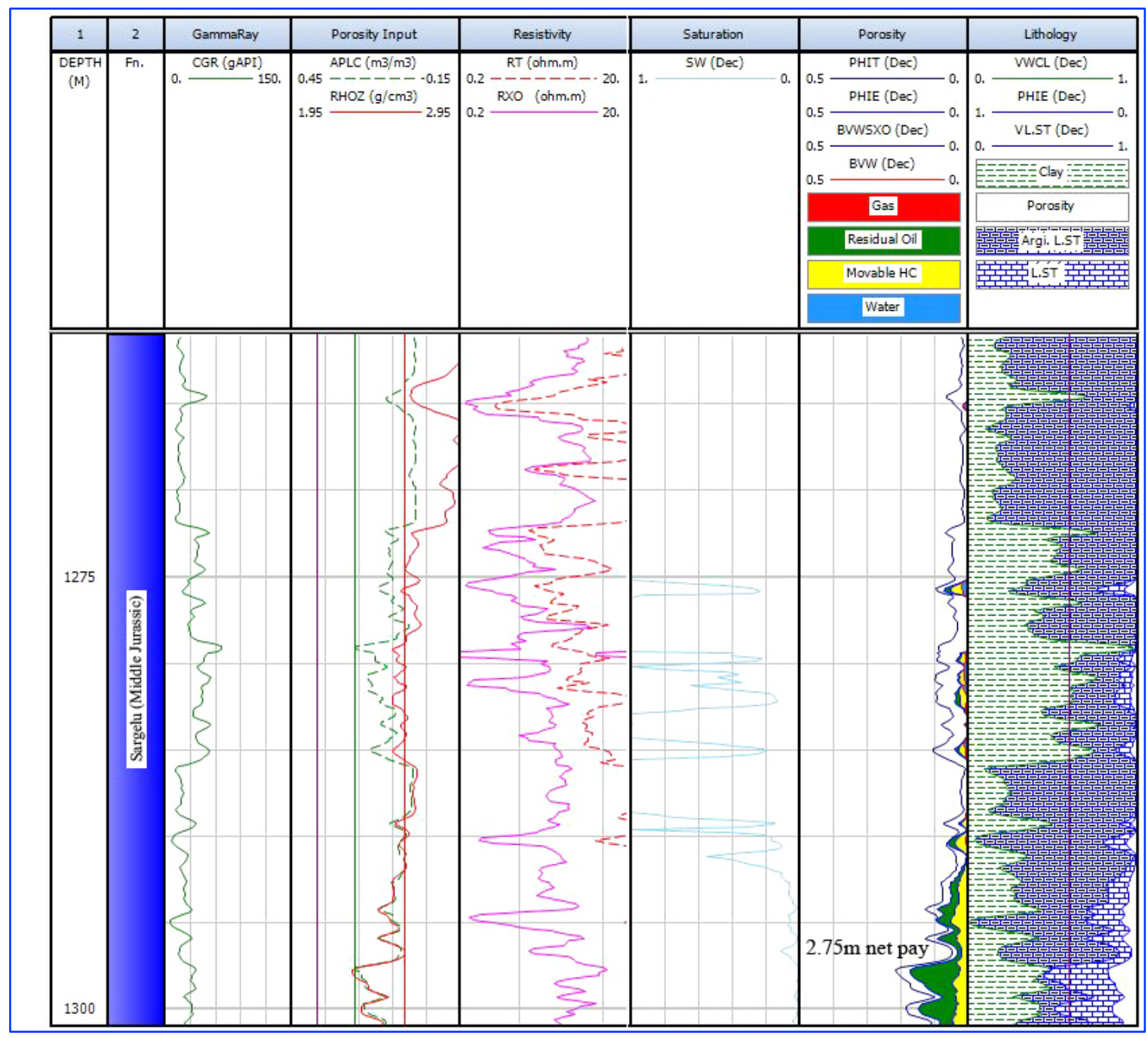

Fig. 5. Computer Processed Interpretation (CPI) for the Sargelu Formation in well Atrush-3

\section{Source Rock Evaluation}

A petroleum source rock is defined as any rock that has the capability to generate and expel enough hydrocarbons to form an accumulation of oil and gas (Hunt, 1996). Typical source rocks, frequently shales or limestones, contain roughly $1 \%$ organic matter and as a minimum $0.5 \%$ total organic carbon (TOC), while a rich source rock might have as much as $10 \%$ organic matter. Rocks of marine source are inclined to be oil-prone, while terrestrial source rocks in more circumstance produce gas. Protection of organic matter starved of degradation is critical to make a good source rock, and essential for a comprehensive petroleum system (Tissot and Walte, 1984). One of the dominant purposes of organic geochemistry is to classify organic matter from sedimentary rocks. Nowadays, pyrolysis method is commonly used to provide data on the maturity and form of source rocks in different sedimentary basins. The volume of organic matter within the sedimentary rocks as determined by the total organic 
carbon (TOC wt\%) which is the main quantitative metric to be used when assessing a stratigraphic unit's capacity for petroleum generation (Nunez and Baceta, 1994). Peters (1986) and Leckie et al. (1988) testified that the total organic carbon (TOC) values between 0.5-1.0 $w t \%$ specify a decent source of generative potential for rock, and ranging between $1-2 \mathrm{wt} \%$ represent strong generative potential, whereas TOC values above $2 \mathrm{wt} \%$ indicate very good potentiality. TOC values in the Sargelu Formation ranged from 3.56-5.02 wt $\%$ in the well Atrush-3, and 0.74-3.22 wt\% in the Warte outcrop section (Table 2). Consequently, the quantity of organic matter in both Warte and well Atrush-3 within the black shale of the Sargelu Formation is good to very good source material (Fig. 6). Due to abundant residual hydrocarbon (S2) in the subsurface beds, the hydrogen index (HI) values surpassed $500 \mathrm{mg}$ $\mathrm{HC} / \mathrm{g}$ TOC (ranges 512-603), but the values varied from 207 to $467 \mathrm{mg} \mathrm{HC} / \mathrm{g}$ TOC, in the outcrop beds. By contrast, values of the oxygen index (OI) in both sections is low, ranges from $3-138 \mathrm{mg} \mathrm{CO}_{2} / \mathrm{g}$ TOC. The average $\mathrm{T}_{\max }$ for the samples of the Sargelu Formation was $444{ }^{\circ} \mathrm{C}$, with an average production index (PI) value of 0.14 (Table 2). These reveal that the Sargelu Formation is in the mature stage (oil window) and types of kerogen vary between Type II and II-III (Fig. 7). The same results have been appealed by Al-Ahmed (2006); Abdula (2015) and Al-Atroshi et al., (2020).

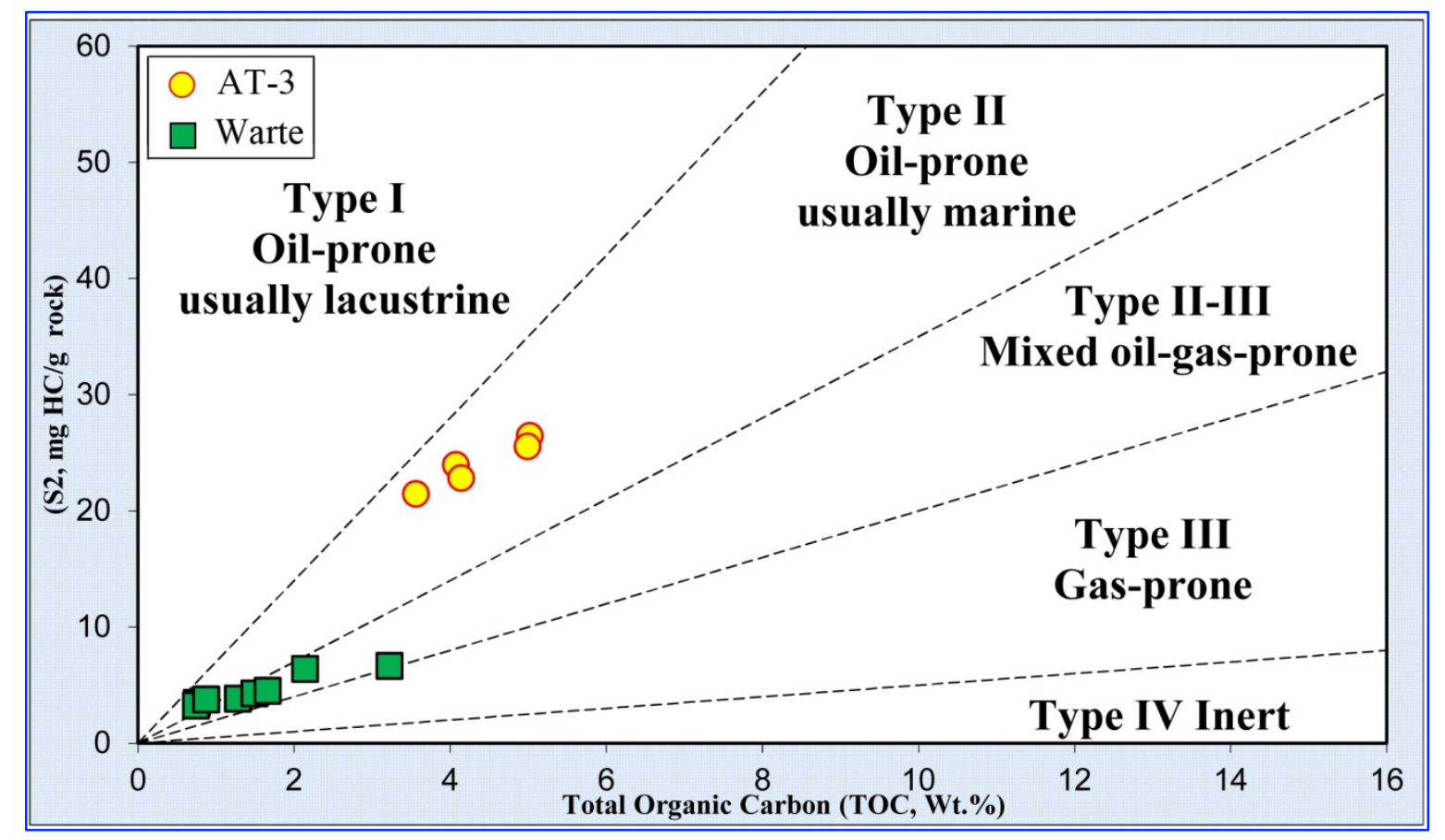

Fig. 6. The kerogen types of the Sargelu Formation in the studied sections 


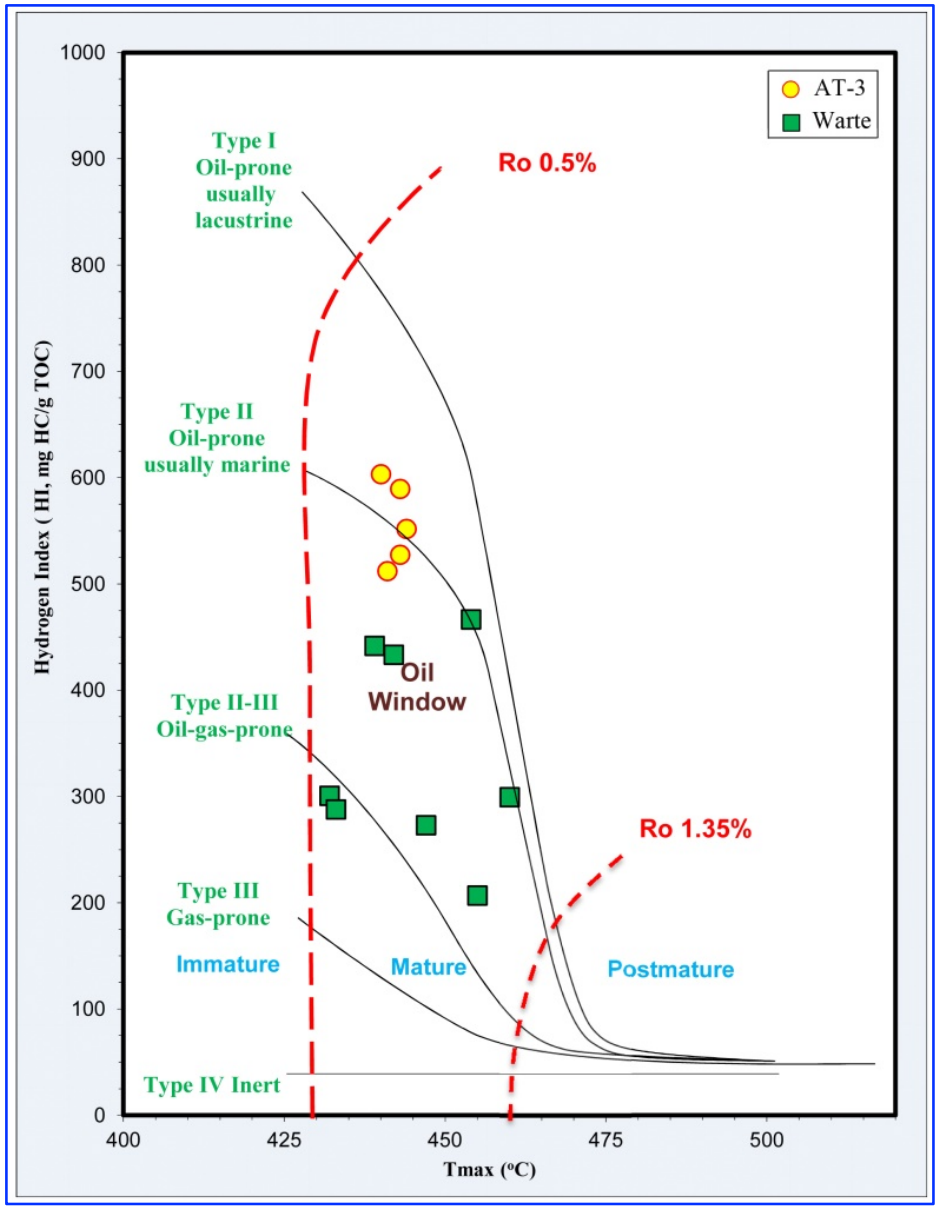

Fig. 7. Maturation level in the studied formation

Table 1. Pyrolysis results of the Sargelu Formation in both sections

\begin{tabular}{|c|c|c|c|c|c|c|c|c|c|c|}
\hline 氙 & $\begin{array}{l}\text { Depth } \\
\text { (m) } \\
\text { Distance } \\
\text { (m) }\end{array}$ & $\begin{array}{l}\text { TOC } \\
\text { wt\% }\end{array}$ & $\begin{array}{c}\text { S1 } \\
\mathrm{mg} / \mathrm{g}\end{array}$ & $\begin{array}{c}\text { S2 } \\
\mathrm{mg} / \mathrm{g}\end{array}$ & S3 & HI & OI & $\begin{array}{c}\mathbf{T}_{\max } \\
{ }^{\mathbf{o}} \mathbf{C}\end{array}$ & PI & Ro\% \\
\hline \multirow{5}{*}{$\stackrel{?}{\stackrel{1}{4}}$} & 1262 & 4.07 & 4.9 & 23.99 & 0.35 & 589 & 9 & 443 & 0.17 & 0.66 \\
\hline & 1269 & 4.14 & 3.88 & 22.85 & 0.41 & 552 & 10 & 444 & 0.15 & 0.71 \\
\hline & 1276 & 5.02 & 4.2 & 26.48 & 0.14 & 527 & 3 & 443 & 0.14 & 0.68 \\
\hline & 1279 & 4.99 & 3.1 & 25.56 & 0.31 & 512 & 6 & 441 & 0.11 & 0.72 \\
\hline & 1285 & 3.56 & 3.99 & 21.48 & 0.55 & 603 & 15 & 440 & 0.16 & 0.69 \\
\hline \multirow{8}{*}{ 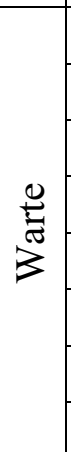 } & 2 & 1.28 & 0.71 & 3.85 & 1.77 & 301 & 138 & 432 & 0.16 & 1.02 \\
\hline & 14 & 1.49 & 0.54 & 4.29 & 1.19 & 288 & 80 & 433 & 0.11 & 1.04 \\
\hline & 28 & 2.14 & 0.98 & 6.41 & 0.18 & 300 & 8 & 460 & 0.13 & 0.88 \\
\hline & 36 & 3.22 & 0.99 & 6.66 & 0.16 & 207 & 5 & 455 & 0.13 & 1.01 \\
\hline & 44 & 0.75 & 0.47 & 3.5 & 0.14 & 467 & 19 & 454 & 0.12 & 0.78 \\
\hline & 55 & 1.66 & 0.82 & 4.53 & 0.19 & 273 & 11 & 447 & 0.15 & 0.75 \\
\hline & 62 & 0.74 & 0.59 & 3.27 & 0.15 & 442 & 20 & 439 & 0.15 & 0.74 \\
\hline & 70 & 0.87 & 0.63 & 3.77 & 0.11 & 433 & 13 & 442 & 0.14 & 0.77 \\
\hline
\end{tabular}


On the other hand, eight rock samples from the Sargelu Formation were analyzed by GC instrument (Fig. 8) and (Table 3). The GC experiments are commonly used to examine biological markers. Pristane/phytane ratio and carbon preference index (CPI) can provide knowledge about the organic source materials, the state of the environment and the thermal maturity. Such compounds are produced by degradation of the phytal side chain chlorophyll at the time of sedimentary deposition (Peters et al., 2005). Regularly pristane/phytane ratio is used for determining redox conditions during deposition of sediments. $\mathrm{Pr} / \mathrm{Ph}$ ratios significantly below unity could be taken as a petroleum origin measure and/or a highly reduced depositional environment; more than 3 indicate to terrestrial sediments (Hunt, 1996). By projecting the measured $\mathrm{Pr} / \mathrm{n}-\mathrm{C}_{17}$ and $\mathrm{Ph} / \mathrm{n}-\mathrm{C}_{18}$ on special cross plot proposed by Shanmugam (1985) (Fig. 9), it is clear that the formation in the studied sections contain organic matter of a marine to mixed source kerogen II \& II-III. From the same plot and regarding the maturation states of the existed organic matters, it seems that the samples are located within the mature stage. The values of the $\mathrm{Pr} / \mathrm{Ph}$ ratios are generally less than 1 (average 0.72), such a condition indicates algal organic detritus in the kerogen of a marine source rock deposited under anoxic (reducing) condition; the same conclusion has been claimed by Faqi et al., (2018). CPI which derived from the distribution of n-alkanes by dividing the total of the odd carbon-numbered alkanes $\left(\mathrm{C}_{25}-\mathrm{C}_{33}\right)$ into the sum of even carbonnumbered alkanes $\left(\mathrm{C}_{24}-\mathrm{C}_{34}\right)$, (Tissot and Welte, 1984 and Taylor et al., 1998), used to identify maturity. CPI values close to one indicate mature samples (Maioli et al., 2011). The values of the CPI in eight nominated samples were close to one, indicating mature stage and reducing condition (Fig. 10).

Table 2. Isoprenoids/n-alkane values of the Sargelu Formation in the studied sections

\begin{tabular}{|c|c|c|c|c|c|}
\hline 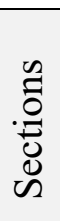 & Depth (m) & 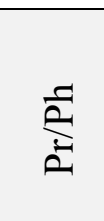 & 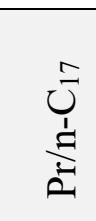 & $\frac{U_{1}^{\infty}}{\frac{1}{2}}$ & $\overrightarrow{0}$ \\
\hline \multirow{3}{*}{$\stackrel{\leftrightarrow}{\mathscr{H}}$} & 1270 & 0.76 & 0.73 & 0.81 & 0.99 \\
\hline & 1279 & 0.83 & 0.80 & 0.87 & 0.97 \\
\hline & 1282 & 0.77 & 0.74 & 0.85 & 0.98 \\
\hline \multirow{5}{*}{ 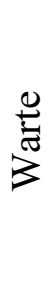 } & 17 & 0.68 & 0.86 & 0.83 & 0.99 \\
\hline & 28 & 0.67 & 0.85 & 0.82 & 0.98 \\
\hline & 44 & 0.70 & 0.91 & 0.89 & 0.99 \\
\hline & 55 & 0.69 & 0.88 & 0.87 & 0.98 \\
\hline & 67 & 0.70 & 0.87 & 0.85 & 0.97 \\
\hline
\end{tabular}




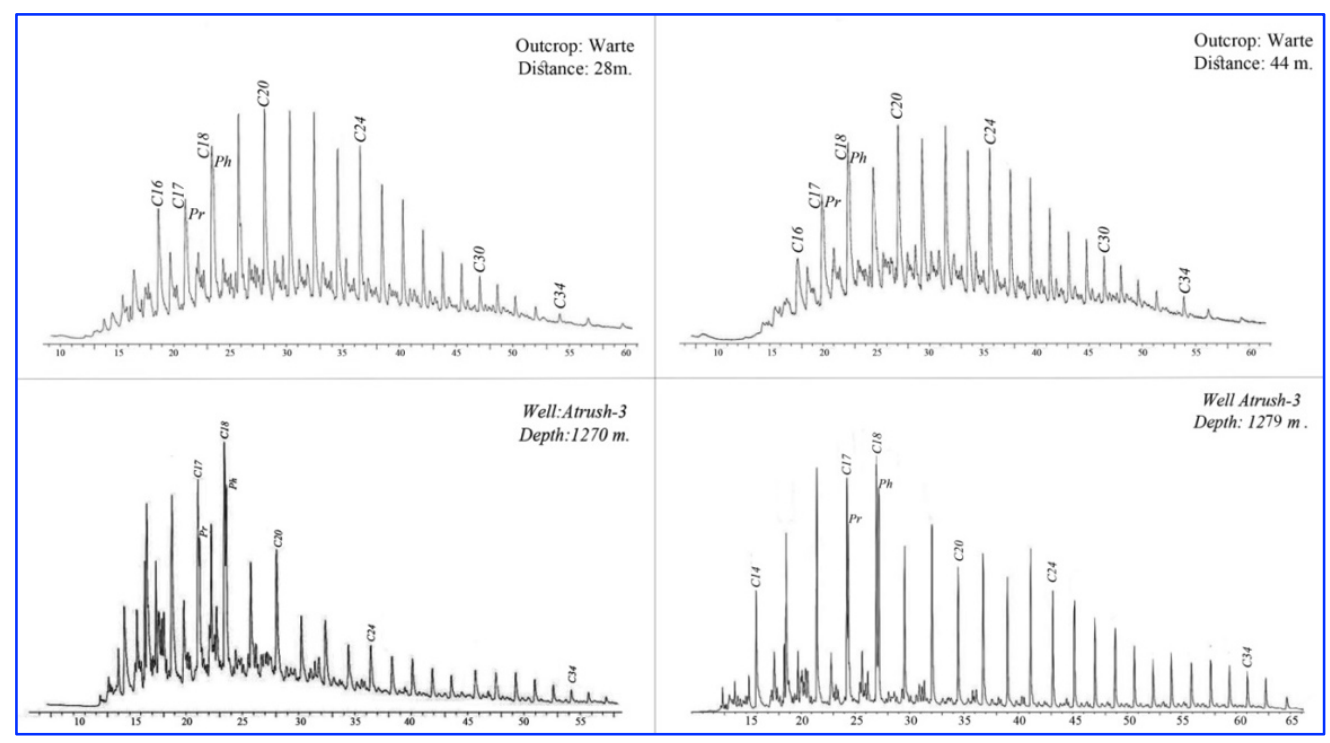

Fig. 8. Isoprenoids/ n-alkanes distribution of the Sargelu Formation in both sections

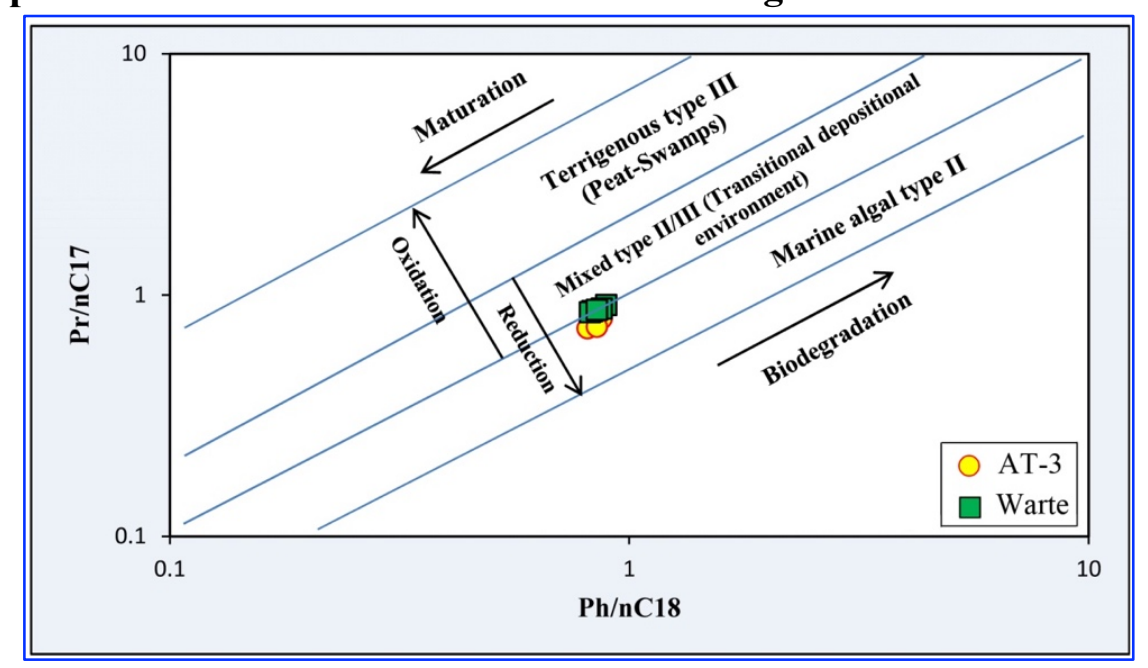

Fig. 9. Kerogen types, maturity and different source material of the Sargelu Formation in the studied sections

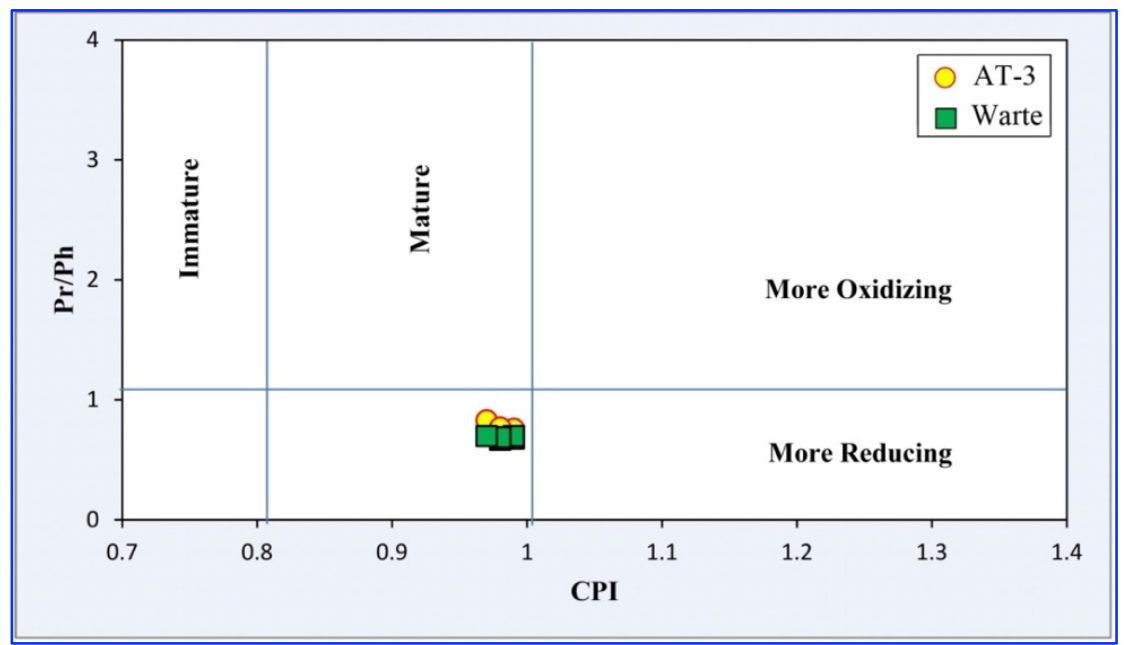

Fig. 10. Maturity and redox conditions of the Sargelu Formation in the studied sections 
Optical indications of maturity are also used to determine the maturity of the formation. Based on Tissot and Walte, 1984 and Ronald and Lewis, 2007, vitrinite reflectance is the most common method. The term Ro\% relates to the amount of incident light reflected back from the vitrine surface via the microscope. Waples (1988) assumed that the vitrinite reflectance of $0.6 \%$ signified the early stage of oil generation, whereas the peak of oil generation was $0.8 \%$ and the late stage of oil generation was $1.35 \mathrm{Ro} \%$. The value of the vitrinite reflectance in the studied core samples varies from $0.66-0.72 \%$ in well Atrush-3 (Table 2) which indicates for mature and peak oil window, whereas in the outcrop segment the formation has 0.74 to $1.04 \mathrm{Ro} \%$, which also indicates for mature stage and mostly to produce oil and some condensate gas (Fig. 11). Another maturity assessment is thermal alteration index (TAI). Thermal alteration index means examined palynomorphs (spores and pollens) under a microscope with emitted light. When the colors of the extracted microfossils shifted with expanded burial depth from light to dark can be used to assess maturity (Hunt, 1996 and Peter, 1986).

Staplin (1969) observed that the immature organic matter is yellow which shift to orange or yellow-brown during diagenesis, with increased temperature it turns to brown during catagenesis, and then to black during metagenesis. Based on Pearson (1984) the color change of the palynomorphs in the selected samples observed optically to calculate the thermal alteration index (TAI) and evaluate the level of maturity in Sargelu Formation. TAI color scale from 1-5 represent kerogen color changes from light yellow to dark yellow, light brown to dark brown and black. The yellow is immature (only dry biogenic gas and heavy oil is being found), the light brown and brown is mature (oil and gas generate); dark brown and black means postmature (mainly dry gas). The organic matters are observed optically in both segment of the Sargelu Formation indicate mature stage with a range of colors between yellow brown and brown (TAI 2+ and 3) (Fig. 12), indicating advanced stage and the formation's ability to generate almost all oil and some condensate gas in an appropriate situation; also Al-Ameri et al. (2014) claimed that the Sargelu Formation in the wells Ajeel-8 and TAQ-TAQ-1 is within the oil window with TAI equal to 3-, 3+, based on microspore the color changed from yellowish brown to brown. 


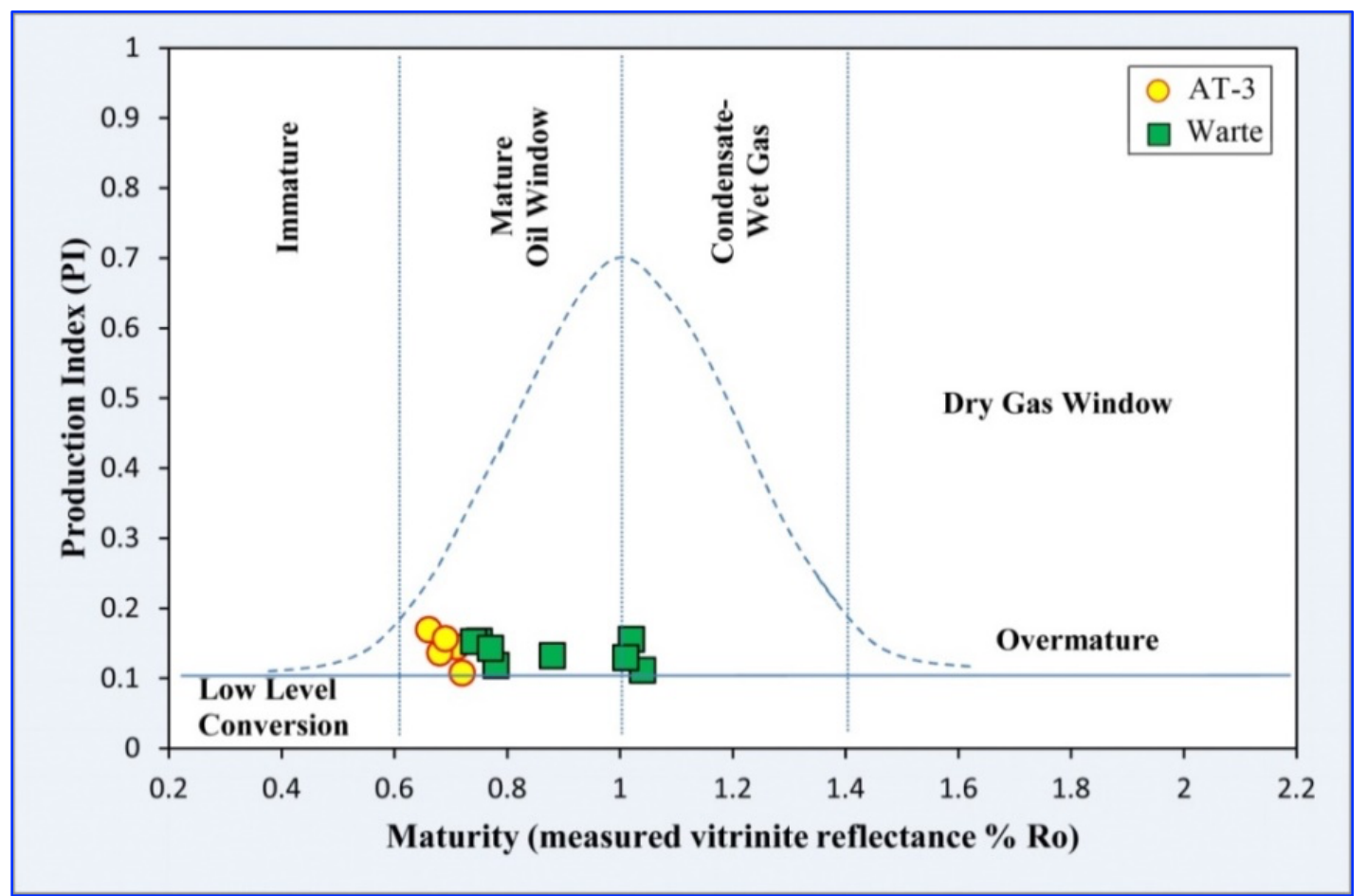

Fig. 11. The PI versus Ro showing maturation level in the studied formation

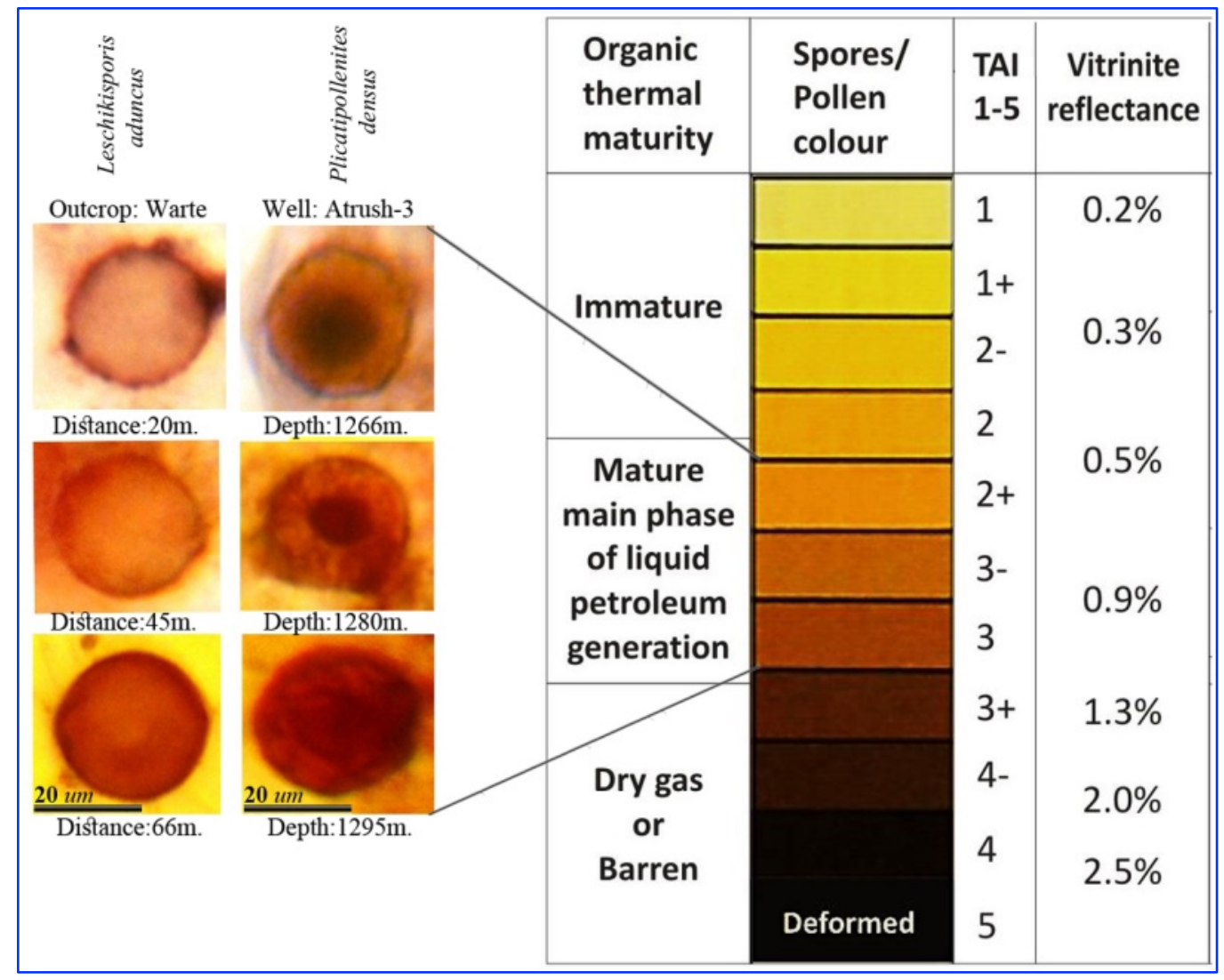

Fig. 12. Thermal alteration index and vitrinite reflectance of the Sargelu Formation 


\section{CONCLUSIONS}

The Sargelu Formation in the areas under study (Well Atrush-3 and Warte outcrop section) includes both source and reservoir rocks. Based on the geochemical tests, the formation has very good potentials to generate enough hydrocarbons (oil and gas). Additionally, the black shales between the limestone beds can be considered as a good source for hydrocarbons generation because the shales are rich in organic matters and have reached the level of maturation zone. The limestone units in the subsurface section have adequate porosity and permeability and can sufficiently accommodate mobile hydrocarbons.

\section{ACKNOWLEDGMENTS}

First, I want to express my sincere gratitude to MNR to provide the data for this study. Special thank goes to Mr. Bzhar and Mr. Goran from Soran University for their help during analyzing samples. The authors are very grateful to the Editor in Chief Prof. Dr. Salih M. Awadh, the Secretary of Journal Mr. Samir R. Hijab and the Technical Editor Dr. Heba S. AlMimar for their great efforts and valuable comments.

\section{REFERENCES}

Abdula, R. A., 2015. Hydrocarbon potential of Sargelu Formation and oil-source correlation, Northern Iraq. Arabian Journal of Geosciences, 8: 5845-5868.

Al-Ahmed, A. A., 2006. Organic Geochemistry, Palynofacies and Hydrocarbon Potential of Sargelu Formation (Middle Jurassic) Northern Iraq. Ph.D. Thesis. University of Baghdad (Unpublished), 120p.

Al-Ameri, T. K., Najaf, A. A., Al-Khafaji, A. S., Zumberge, J., and Pitman, J., 2014. Hydrocarbon potential of the Sargelu Formation, North of Iraq. Arabian Journal of Geosciences, 7: 987-1000.

Al-Atroshi, S. J., Sherwani, G. H., and Al-Naqshbandi, S. F., 2020. Assessment the hydrocarbon potentiality of the Middle Jurassic Sargelu Formation, Northern Iraq. Iraqi Geological Journal, 53:1-15.

Altinli, I. E., 1966. Geology of Eastern and Southeastern Anatolia, Turkey", Bulletin of Mineral Research Exploration Institute of Turkey, Foreign Edition, Ankara, 60: 35-76.

Aqrawi, A. A. M., Goff, J. C., Horbury, A. D., and Sadooni, F. N., 2010. The Petroleum Geology of Iraq: Scientific Press, 242p.

Archie, G. E., 1942. The electrical resistivity $\log$ as an aid in determining some reservoir characteristics. Petroleum Transactions of the AIME, 146: 54-62.

Asquith, G., and Krygowski, D., 2004. Basic Well Log Analysis. $2^{\text {nd }}$ ed. 244 p.

Bellen, R. C., Dunnington, H.V., Wetzel, R., and Morton, D., 1959. Lexique Stratigraphic International. Asie, Fasc. 10a, Iraq, Paris, 333p.

Buday, T., 1980. The Regional Geology of Iraq, Volume I, Stratigraphy and Pale Geography, Dar Al-Kutub publishing house, University of Mosul, Iraq, 445p.

Darwin, V. E., and Julian, M. S., 2007. Well Logging for Earth Scientist, $2^{\text {nd }}$ ed. Springer, the Netherlands, 629$634 \mathrm{pp}$.

Dresser, A., 1975. Log Interpretation Fundamentals, Technology \& Engineering, Mining. Houston, 107p.

Dubertret, B., 1966. Liban, Syrie et bordure des pays voisions, notes and memories Moyen orient, Paris, 8: 251258.

Faqi, A., Ali, A., Abdullah, B., and Bowden, S., 2018. Source rock evaluation and lateral changes in thermal maturity of the Sargelu Formation (Middle Jurassic) in Northern Iraq. UKH Journal of Science and Engineering, 2: 7-17.

Hunt, J. M., 1996. Petroleum Geochemistry and Geology. $2^{\text {nd }}$ ed, Cambridge, USA, 743p. 
Jassim, S. Z., and Goff, J. C., 2006. Geology of Iraq. Brno, Czech Republic: Dolin, Prague and Moravian Museum, 341p.

Leckie, D. A., Kalkreuth, W. D., and Snowdon, L. R., 1988. Source rock potential and thermal maturity of lower Cretaceous strata, Moukman Pass area British Colombia. AAPG Bulletin, 72: 820-838.

Maioli, O. L., Rodrigues, K. C., Knoppers, B. A., and Azevedo, D. A., 2011. Distribution and sources of aliphatic and polycyclic aromatic hydrocarbons in suspended particulate matter in water from two Brazilian estuarine systems, Continen. Shelf Resources, 31:1116-1127.

Mamaseni, W. J., Naqshabandi, S. F., and Al-Jaboury, F. K., 2019. Palynofacies and paleoenvironment of Late Jurassic-Early Cretaceous Formations at Duhok Basin, Northern Iraq. Iraqi Geological Journal, 52 (1): 61-82.

Nunez-Betelu, L., and Baceta, J. I., 1994. Basic and application on Rock- Eval/TOC Pyrolysis: an example from the upper Paleocene/Lowermost Eocene in the Basque Basin, Western Pyrenees. MUNIBE. Ciencias Naturales, 43-62pp.

Pearson, D. L., 1984. Pollen/Spore Color "Standard" version 2. Springer (2 $2^{\text {nd }}$ ed.), Dordrecht, Netherlands, 581613.

Peters, K. E., 1986. Guidelines for Evaluating Petroleum Source Rock Using Programmed Pyrolysis. AAPG Bulletin., 70: 318-329.

Peters, K. E., Walters, C. C., and Moldowan, J. M., 2005. The Biomarker Guide, $2^{\text {nd }}$ Volume, Biomarkers and Isotopes in Petroleum Systems and Human History, United Kingdom at the Cambridge University Press, $700 \mathrm{p}$.

Ronald, F., B., and Lewis, G., 2007. The Barnett Shale in Southeastern New Mexico: Distribution, Thickness, and Source Rock Characterization: New Mexico Bureau of Geology and Mineral Resources, Open-File Report 502, $56 \mathrm{pp}$.

Selley, R. C., 1998. Elements of Petroleum Geology. San Diego, London, UK. $2^{\text {nd }}$. Academic press, 471p.

Shamaran Petroleum Corporate 2013. Internal report, the final well report of Atrush-3 well, (unpublished report).

Shanmugam, G., 1985. Significance of coniferous rain forests and related oil, Gippsland Basin, Australia. AAPG Bulletin., 69: 1241-1254.

Staplin, F. L., 1969. Sedimentary organic matter, organic metamorphism and oil and gas occurrence. Bulletin Canada Petroleum Geology, 17: 46-66.

Taylor, G. H., Teichmuller, M., Davis, A., Diessel, C. F. K., Littke, R., and Rober, P., 1998. Organic Petrology. Handbook, Berlin; Stuttgart: Gebrudre Borntraeger, 704p.

Tissot, B.P., and Welte, D. H., 1984. Petroleum Formation and Occurrence: A New Approach to Oil and Gas Exploration. $2^{\text {nd }}$. Springer, Verlag, Berlin, 702p.

Waples, D. W., 1988. Time and temperature in petroleum formation: application of Lopatin's method to petroleum exploration. AAPG Bulletin., 64: 916-926. 